\title{
Plant fruits used as food by the Dayak community of Tamambaloh in Labian Ira'ang Village, Kapuas Hulu District, Indonesia
}

\author{
MARKUS IYUS SUPIANDI ${ }^{1, \boldsymbol{v}}$, LELIAVIA ${ }^{1}$, DIDIN SY AFRUDDIN ${ }^{1}$, YUNIARTI ESSI UTAMI $^{1}$, RUFINA SEKUNDA ${ }^{2}$ \\ ${ }^{1}$ Program of Biology Education, STKIP Persada Khatulistiwa Sintang. Jl. Pertamina Km 4, Sengkuang, Sintang 78614, West Kalimantan, Indonesia. \\ Tel./fax.: +62-565-21135, `email: msupiandi@gmail.com. \\ ${ }^{2}$ Sekolah Menengah Pertama Negeri 3 (State Junior High School No. 3) Sungai Tebelian. Sintang 78661, West Kalimantan, Indonesia
}

Manuscript received: 1 February 2019. Revision accepted: 12 June 2019.

\begin{abstract}
Supiandi MI, Leliavia, Syafruddin D, Utami YE, Sekunda R. 2019. Plant fruits used as food by the Dayak community of Tamambaloh in Labian Ira'ang Village, Kapuas Hulu District, Indonesia. Biodiversitas 20: 1827-1832. The Dayak Tamambaloh community has a long tradition of using plants as source of food. However, this knowledge of using the plants as food has not been scientifically documented. The objectives of this study were to identify the species of plants, especially fruit yielding plants, that which were used as food, and to document the methods of their processing practiced by Dayak Tamambaloh community. This study was conducted through the literature survey, interviews and field surveys in Labian Ira'ang Village, Kapuas Hulu District, Indonesia. The results of this study showed that Dayak Tamambaloh community in Labian Ira'ang Village use fruits of as many as 60 species of plants for edible purposes. They belonged to 29 plant families. The families with the highest percentage of fruit yielding plants were Moraceae $(10 \%)$ and Cucurbitaceae (10\%). The food plants were mainly obtained from forests $(58.33 \%)$, gardens (16.67\%), house yards (15\%), river banks (5\%) and hills (5\%).
\end{abstract}

Keywords: Dayak, ethnobotany, food plants, Tamambaloh, traditional

\section{INTRODUCTION}

Dayak Tamambaloh is a community belonging to Dayak tribe, living in the regions bordering Indonesia and Malaysia. Administratively, Dayak Tamambaloh community belong to Labian Ira'ang Village, Batang Lupar Sub-district, Kapuas Hulu District, West Kalimantan Province, Indonesia. This village is around 2.370 hectares in area, with rich biodiversity. Plants, especially those which are used traditionally as sources of food by local communities, form a major component of the biodiversity heritage of this village. According to Nopandry (2007), the traditional communities have local wisdom which has the potential and strength for managing forest areas. The coexistence of local communities along with forests for hundreds of years is a proof for forest conservation by traditional civilizations.

According to Keraf (2002), local wisdom is all forms of knowledge, belief, understanding, or insight as well as customs or ethics that guide human behavior throughout their life within the ecological community. Tamalene (2016) says that local wisdom is a part of local culture that is formed through a learning process by observing, testing, practicing and spreading to others. Such local wisdom is reflected in the habit of Dayak Tamambaloh community in utilizing local plants to fulfill their daily food needs. Insight into the use of local plants is obtained by the community through inheritance from parents, and also from relatives and others. According to Tamin and Arbain (1995), knowledge in traditional society has been hereditary. However, this valuable local wisdom is threatened and gradually disappearing mainly because of activities that reduce the availability of food plants in local forests. Hulyati et al. (2014) stated the advancement of science and technology will make the youth to forget their own traditional ways of life and encourage them to adopt outside cultural regimen.

Ethnobotany can be understood as the relationship between plants and a specific ethnicity (community groups) in various parts of the world and society in general as well as emphasis on a particular culture and its traditions (Martin 1995; Tamin and Arbain 1995; Balick and Cox 1996; Cotton 1996; Munawaroh 2000; Pie and Xiu 2002; Choudhary et al. 2008; Tesfaye et al. 2009; Mesfin et al. 2013). Ethnobotany finds out how society considers botany on the cultural system (Tamin and Arbain, 1995). It is used to discover how precious plants are for certain tribes (Tjitrosoepomo 2005). Ethnobotanical research is very important for the purpose of biodiversity conservation (Martin 1995; Cunningham 2001; Alexiades 2003; Aryal 2009; Diame 2010; Reta 2010; Pieroni et al. 2014; Supiandi et al. 2019).

The use of food plants by Dayak Tamambaloh community is facing various threats, such as (i) majority of people who of use these plants are not putting any effort to preserve them (Sutedjo 2004), (ii) clearing of forests due to forest fires and, palm and rubber plantations; (iii) the spraying of chemicals and the conversion of plantation land (Due 2013), and (iv) construction of roads, offices, ports, airports, large estates, community agriculture, mining, dams, industrial estates, urban settlements, irrigation networks, electricity networks and transmigration 
(Gunawan 2014). These activities may eliminate the biodiversity existing in natural ecosystems. Therefore, steps are needed to ensure that local forests remain conserved and the local cultural values centered around them are also preserved in the community.

To prevent the loss of biodiversity in general and to support the efforts of preserving food plants used by Tamambaloh Dayak community, in particular, it was necessary to conduct a detailed ethnobotanical research about food plants in this community. The results of such an ethnobotanical study regarding edible fruit yielding plants are presented in this paper.

\section{MATERIALS AND METHODS}

\section{Research site and time}

This research was carried out in Dayak Tamambaloh community in Labian Ira'ang Village, Batang Lupar Subdistrict, Kapuas Hulu District, West Kalimantan Province, Indonesia. It was conducted during August and September 2018. Labian Ira'ang village is administratively included in Batang Lupar Sub-district, Kapuas Hulu District, West Kalimantan Province. The Labian Ira'ang village is bordered by Mensiau Village in the north, Setulang Village in the east, Abau River Village in the south; Labian Village in the west. Labian Ira'ang Village, Batang Lupar Subdistrict, Kapuas Hulu District, West Kalimantan has an area about $2.370 \mathrm{Ha}$. The population of Labian Ira'ang village is about 455 people with the 126 of heads of household. There are 242 males and 213 females. This includes Bakul hamlet with 219 people (62 heads of household), Kereng Lunsa hamlet with 195 people (51 heads of household), and Sembawang hamlet with 43 people (13s head of household). Most of the lowlands of the study area are used for fields, vegetable plantations, settlements, and housing. The rest of the land is forest and set-aside land. The upland is used for natural rubber and fruit plantations. The map of the research area is presented in Figure 1.

\section{Data collection}

Data presented in this study consist of both primary data and secondary data (table 1). Primary data was about the diversity and use of fruit plants, such as their local names, scientific names, families, habitat, parts being used, and method of processing and uses. Meanwhile, secondary data consist of general conditions of the research location including demographic and socio-economic conditions.

Interview is a data collection technique used to obtain verbal information through conversations with people or respondents about research topics (Salerno et al. 2005). Interview employed in this study was semi-structured type. The respondents being interviewed were selected based on snowball sampling technique. Snowball sampling is a technique whose application starts from key informants (adat leaders) who can then provide further information needed in research. The respondent on the research is 20 people. Further, field observations were conducted for verifying information on food plant species obtained from interviews with traditional leaders, village heads, traditional healers/physicians and other people of the communities who had an understanding of food plants.

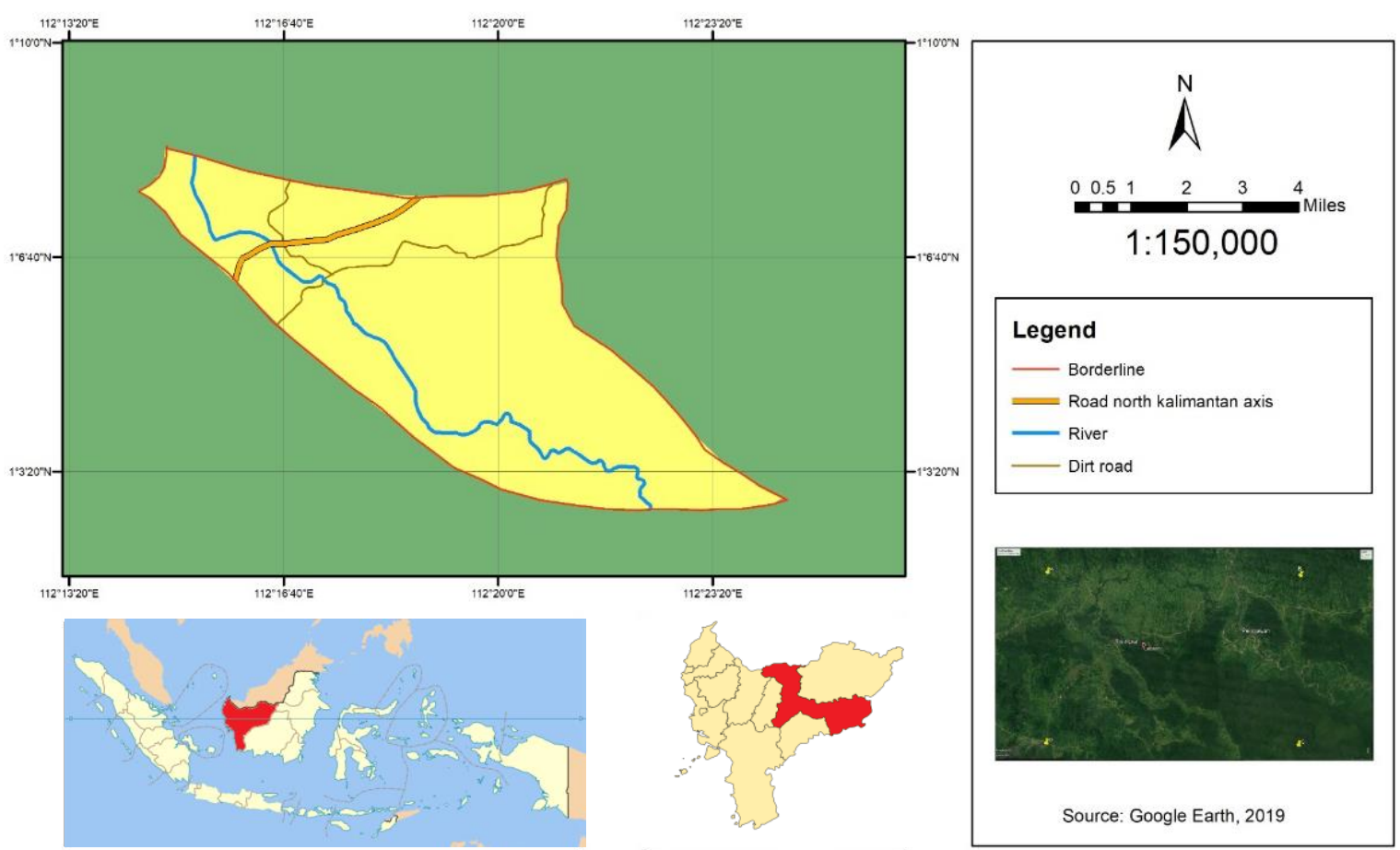

Figure 1. Labian Ira'ang Village Administrative Area, Batang Lupar Sub-district, Kapuas Hulu District, West Kalimantan Province, Indonesia 
Table 1. Data collected

\begin{tabular}{|c|c|c|c|}
\hline Data collected & & Description & Methods \\
\hline $\begin{array}{l}\text { General conditions of the } \\
\text { research location }\end{array}$ & (Secondary) & $\begin{array}{l}\text { Location and area } \\
\text { Demographics } \\
\text { Socio-economic conditions }\end{array}$ & Literature study \\
\hline The diversity of food plants & (Primary) & $\begin{array}{l}\text { Local names } \\
\text { Scientific names } \\
\text { Families } \\
\text { Habitat } \\
\text { Parts used } \\
\text { Method of processing and uses }\end{array}$ & $\begin{array}{l}\text { Field observation, interview, and } \\
\text { literature study }\end{array}$ \\
\hline
\end{tabular}

\section{Data analysis}

Identification of plant species was done to determine the scientific name of the species. Identification was done by (i) using reference books about plants, (ii) through photos from the internet (sites: www.theplantlist.org; www.catalogueoflife.org; wcsp.science.kew.org; epic .kew.org; biodiversitylibrary.org; www.google.co.uk), and (iii) discussions with botanists and other plant experts.

Food plants that are used by the Dayak Tamambaloh community are grouped by family and family percentage was calculated using the following formula (Desuciani 2012):

Percentage of a family $=\frac{\sum \text { species from certain family }}{\sum \text { total species }} \times 100 \%$

The percentage of food plants based on their habitat types was calculated based on the number of species used from various habitat types such as forests, gardens, fields, yards, and others. The percentage of species of habitat types was calculated by the formula (Farneubun 2014) as follows:

Percentage of species from a habitat type $=\frac{\sum \text { species from certain habitat }}{\sum \text { speciesfrom all habitat }} \times 100 \%$

\section{RESULTS AND DISCUSSION}

\section{Diversity of fruit plants used as food}

Interviews and field observations with Dayak Tamambaloh community indicated that they are using a total of 60 species of edible fruit yielding plants. The detailed list of these plants is presented in Table 2 .

The 60 species of fruit plants belonged to 29 families. They were found in various kinds of habitats, such as forests, gardens, yards, river banks, and hills. The processing methods included boiling, sauteing, frying, burning, pounding, and many are eaten directly. Dayak Tamambaloh community was still using the traditional methods to process fruits.

\section{Familywise distribution of fruit yielding plants}

The number of fruit yielding plants belonging to each of the 29 plant families and their percentage is shown in table 3 .

The families with the highest percentage are Moraceae (10\%) and Cucurbitaceae (10\%). The Moraceae family includes the kakatup (Broussontia papyrifera (L.) Vent.), karam (Ficus variegata Blume.), timadak (Artocarpus integer Merr.), kundur (Artocarpus camansi (Parkinson) Fosberg), takalong (Artocarpus sericicarpus Jarrett), and sukun (Artocarpus altilis (Parkinson) Fosberg). The fruits of Moraceae family are widely used as food because they have high nutritional values (Pitojo 2005). Kakatup (Broussontia papyrifera) has been reported to be useful in many ways. For example, (i) fruit and leaf are edible, (ii) leaves used as traditional medicine, and (iii) stem used for making paper and furniture. Ficus is the largest genus in the family Moraceae (Zheng et al. 2006). Lushaini et al. (2015) reported that leaf of karam plant (Ficus variegata Blume.) was used by the community as a vegetable. Lempang and Suhartati (2013) have also reported that young fruits of Artocarpus integer can be used as vegetables while ripe fruit can be eaten fresh or processed. Phytochemical studies on this fruit found the presence of protein, fat, carbohydrate, calcium, phosphorus, iron, vitamin $\mathrm{A}$, vitamin $\mathrm{C}$ and water, and the total energy value was 116 kcal (Astawan 2009). Sukun plants have high economic value because they produce fruits with high nutrient content (Adinugraha et al. 2014). Fruits of sukun are one type of staple food for the Dayak Tamambaloh tribe, which is processed into a variety of dishes and snacks (Widowati 2003; Department of Agriculture 2003; Adinugraha et al. 2014).

The Cucurbitaceae family consists of antimun balao (Gymnopetalum cochinchinense (Lour) Kurz), kapari (Momordica charantia L.), pusut (Luffa acutangula L.), antimun uma (Cucumis sativus L.), lao baute ' (Lagenaria siceraria (Mol.) Standal), and paranggi (Cucurbita moschata Durch). The Cucurbitaceae family is widely used as source of fruits by the Tamambaloh Dayak tribe because: (i) it is easily cultivated, (ii) easy to process, (iii) has high nutritional value, and (iv) almost all parts of the plant can be used as vegetables. 
Table 2. List of edible fruit yielding plants used by Dayak Tamambaloh community, Kapuas Hulu District, West Kalimantan Province, Indonesia

\begin{tabular}{|c|c|c|c|c|}
\hline Local name & Scientific name & Family name & Habitat & Method of processing \\
\hline Antimun balao & Gymnopetalum cochinchinense (Lour.) Kurz. & Cucurbitaceae & Forest & Sauteed \\
\hline Antimun uma & Cucumis sativus $\mathrm{L}$. & Cucurbitaceae & Forest & Boiled, sauteed \\
\hline Aratak & Vigna sinensis (L.) Savi ex Hausskn. & Leguminosae & Garden & Boiled, eaten rawor sauteed \\
\hline Aratak binuang & Abelmoschus esculentus (L.) Moench. & Malvaceae & Garden & Boiled, sauteed \\
\hline Barangan & Castanea sativa Mill. & Fagaceae & Forest & Boiled \\
\hline Buapang & Capsicum annum $\mathrm{L}$. & Solanaceae & Yard & Pounded, sauteed \\
\hline Bungkang & Syzygium polyanthum (Wight) Walp. & Myrtaceae & Forest & Eaten directly \\
\hline Durian & Durio zibethinus L. & Malvaceae & Forest & Eaten directly, sauteed, boiled \\
\hline Durian balanda & Annona muricata $\mathrm{L}$. & Annonaceae & Forest & Sauteed ( young fruits) \\
\hline Embang-embang & Curculigo orchioides Gaertn. & Liliaceae & Forest & Eaten directly \\
\hline Inyak & Cocos nucifera $\mathrm{L}$. & Arecaceae & Yard & Eaten directly \\
\hline Jagong & Zea mays L. & Poaceae & Garden & Boiled, sauteed, grilled \\
\hline Jambu air & Syzygium aqueum (Burm.f.) Alston. & Myrtaceae & House yard & Eaten directly \\
\hline Jambu karak & Bellucia axinanthera Triana. & Melastomataceae & Forest & Eaten directly \\
\hline Jangkang & Hornstedtia scottiana (F.Muell.) K.Schum. & Zingiberaceae & Hills & Eaten directly \\
\hline Jengkol & Archidendron pauciflorum (Benth.) I.C.Nielsen. & Fabaceae & Forest & Boiled, sauteed \\
\hline Kakabu & Ceiba pentandra (L.) Gaertn. & Malvaceae & Forest & Eaten directly \\
\hline Kakatup & Broussonetia papyrifera (L.) L'Hér. ex Vent. & Moraceae & Hills & Eaten directly \\
\hline Kakawang & Shorea macrophylla (de Vriese) P.S.Ashton & Dipterocarpaceae & Forest & Burned \\
\hline Kalamantik & Nephelium lappaceum L. & Sapindaceae & House yard & Eaten directly \\
\hline Kalamunting & Melastoma affine D. Don. & Melastomataceae & Forest & Eaten directly \\
\hline Kalasi & Passiflora foetida $\mathrm{L}$. & Passifloraceae & Riverbank & Eaten directly \\
\hline Kambunga & Syzygium malaccense (L.) Merr. \& L.M.Perry. & Myrtaceae & Forest & Eaten directly \\
\hline Kandis & Garcinia celebica $\mathrm{L}$. & Clusiaceae & Forest & Eaten directly \\
\hline Kapari & Momordica charantia $\mathrm{L}$. & Cucurbitaceae & Garden & Sauteed \\
\hline Karam & Ficus variegata Blume & Moraceae & Riverbank & Eaten directly \\
\hline Kemantan & Mangifera foetida Lour. & Anacardiaceae & Forest & Eaten directly \\
\hline Koko & Theobroma cacao L. & Malvaceae & Forest & Eaten directly \\
\hline Kucai & Allium schoenoprasum L. & Liliaceae & Garden & Boiled, engulfed, sauteed \\
\hline Kundur & Artocarpus camansi Blanco. & Moraceae & Forest & Boiled, sauteed \\
\hline Kurandik & Dialium indum $\mathrm{L}$. & Leguminosae & Forest & Eaten directly \\
\hline Lao baute' & Lagenaria siceraria (Molina) Standl. & Cucurbitaceae & Garden & Boiled, engulfed, sauteed \\
\hline Lasikan & Myristica fragrans Houtt. & Myristicaceae & Forest & Eaten directly \\
\hline Lenset & Lansium domesticum Corrêa. & Meliaceae & Forest & Eaten directly \\
\hline Limau bali & Citrus grandis (L.) Osbeck. & Rutaceae & Forest & Eaten directly \\
\hline Limudan & Eugeissona utilis Becc. & Arecaceae & Forest & Eaten directly \\
\hline Mangga & Mangifera indica $\mathrm{L}$. & Anacardiaceae & Forest & Eaten directly \\
\hline Maram & Eleiodoxa conferta (Griff.) Burret. & Arecaceae & Forest & Eaten directly \\
\hline Papakan & Durio kutejensis (Hassk.) Becc. & Malvaceae & Forest & Eaten directly, boiled, sauteed \\
\hline Paranggi & Cucurbita moschata Duchesne. & Cucurbitaceae & Garden & Boiled, engulfed, sauteed \\
\hline Pusut & Luffa acutangula (L.) Roxb. & Cucurbitaceae & Garden & Boiled, sauteed \\
\hline Rambean & Baccaurea motleyana (Müll.Arg.) Müll.Arg. & Phyllanthaceae & Forest & Eaten directly \\
\hline Sampolam & Mangifera indica $\mathrm{L}$. & Anacardiaceae & Forest & Eaten directly \\
\hline Sialam & Garcinia $x$ mangostana $\mathrm{L}$. & Clusiaceae & Forest & Eaten directly \\
\hline Singkara & Areca catechu $\mathrm{L}$. & Arecaceae & House yard & Eaten directly \\
\hline Sukun & Artocarpus altilis (Parkinson ex F.A.Zorn) Fosberg. & Moraceae & House yard & Sauteed, fried \\
\hline Takalong & Artocarpus sericicarpus F.M.Jarrett. & Moraceae & Forest & Boiled, sauteed \\
\hline Tamparenget & Aquilegia vulgaris $\mathrm{L}$. & Ranunculaceae & Hills & Eaten directly \\
\hline Tambuk panang & Nephelium lappaceum $\mathrm{L}$. & Sapindaceae & Forest & Eaten directly \\
\hline Tangkalak & Litsea angulata Blume. & Lauraceae & Forest & Eaten directly \\
\hline Tapis & Hornstedtia scyphifera (J.Koenig) Steud. & Zingiberaceae & Forest & Eaten directly \\
\hline Tarung masam & Solanum ferox $\mathrm{L}$. & Solanaceae & Forest & Sauteed, boiled \\
\hline Tarung pipit & Solanum torvum $\mathrm{Sw}$. & Solanaceae & Riverbank & Boiled, rawly eaten, sauteed \\
\hline Tarung sina & Solanum melongena $\mathrm{L}$. & Solanaceae & Garden & Engulfed, sauteed, boiled \\
\hline Timadak & Artocarpus integer (Thunb.) Merr. & Moraceae & Forest & Eaten directly \\
\hline Tomat & Solanum lycopersicum Lam. & Solanaceae & Garden & Eaten directly, sauteed \\
\hline Totolok & Garcinia forbesii King. & Guttiferae & Forest & Eaten directly \\
\hline Umbing & Averrhoa carambola $\mathrm{L}$. & Oxalidaceae & House yard & Eaten directly \\
\hline Unti babari & Ananas comosus (L.) Merr. & Bromeliaceae & Yard & Immediately eaten, sauteed \\
\hline Unti kayu & Carica papaya $\mathrm{L}$. & Caricaceae & Yard & Eaten directly \\
\hline
\end{tabular}


Table 3. Percentage of fruit plants based on family

\begin{tabular}{lcc}
\hline Family & $\begin{array}{c}\text { Number of plant } \\
\text { species }\end{array}$ & Percentage \\
\hline Moraceae & 6 & 10 \\
Cucurbitaceae & 6 & 10 \\
Solanaceae & 5 & 8.33 \\
Malvaceae & 5 & 8.33 \\
Arecaceae & 4 & 6.67 \\
Anacardiaceae & 3 & 5 \\
Myrtaceae & 3 & 5 \\
Sapindaceae & 2 & 3.33 \\
Zingiberaceae & 2 & 3.33 \\
Clusiaceae & 2 & 3.33 \\
Liliaceae & 2 & 3.33 \\
Leguminoceae & 2 & 3.33 \\
Melastomataceae & 2 & 3.33 \\
Passifloraceae & 1 & 1.67 \\
Ranunculaceae & 1 & 1.67 \\
Fagaceae & 1 & 1.67 \\
Phyllanthaceae & 1 & 1.67 \\
Oxalidaceae & 1 & 1.67 \\
Poaceae & 1 & 1.67 \\
Fabeceae & 1 & 1.67 \\
Meliaceae & 1 & 1.67 \\
Annonaceae & 1 & 1.67 \\
Caricaceae & 1 & 1.67 \\
Dipterocarpaceae & 1 & 1.67 \\
Bromeliaceae & 1 & 1.67 \\
Myristicaceae & 1 & 1.67 \\
Rutaceae & 1 & 1.67 \\
Lauraceae & 1 & 1.67 \\
Guttiferae & 1.67 \\
\hline
\end{tabular}

Table 4. Habitat-wise distribution of food plants

\begin{tabular}{lcc}
\hline Habitat & $\begin{array}{c}\text { Number of plant } \\
\text { species }\end{array}$ & Percentage \\
\hline Forest & 35 & 58.33 \\
Garden & 10 & 16.67 \\
Yard & 9 & 15 \\
River Bank & 3 & 5 \\
Hills & 3 & 5 \\
\hline
\end{tabular}

\section{Percentage of food plants based on habitat types}

Number of food plants obtained from different habitats is given in Table 4. Dayak Tamambaloh community use forests, gardens, yards, river banks and hills to plant, maintain, and use plants that yield fruits used as food. It is evident from Table 4 that the most dominant habitat for finding food plants is forest (58.33\% species), gardens (16.67\% species), yards (15\%), river banks (5\%) and hills (5\%). Forests are the most dominant habitat for food plants because Dayak Tamambaloh community in Labian Ira'ang village still have customary forests that are closely guarded and used wisely so that forest sustainability is maintained. Customary forests of Dayak Tamambaloh community make very important contribution towards meeting the present needs of the community and also in the future. Fitrianti (2012) states that forests have an important role in the lives of local communities. Forest, as an environmental unit, is the foundation of life for the community around (Nugraha and Murtijo 2005). Forests are an ecosystem that not only stores natural resources in the form of wood but also biological resources that have social and economic benefits for the environment. Forests, as a repository of biodiversity (flora and fauna), provide many benefits, one of which is to meet food needs (Puspitojati et al. 2014).

The habitat with second higher percentage of species (16.67\%) was garden. According to (Hakim 2014), garden is a piece of landscape with planted species. In Tamambaloh Dayak society, gardens are divided into vegetable and fruit gardens. In the vegetable plantation, they cultivated seasonal plants and horticultural plants. Whitten et al. (1996) stated that the gardens have great advantages for local communities being source of (i) daily necessities like firewood, vegetables and drugs, (ii) forage, (iii) building materials, (iv) income from selling the harvests, (v) products for religious ceremonies, and (vi) aesthetics value. Moreover, as Hakim (2014) explained, gardens also play important role in preserving biological diversity.

The third important habitat of food plants with $15 \%$ species was the yards. The yard is one of the agroforestry complex having a structure and variety of composition (Junaidah et al. 2015). Hakim (2014) explained that yard is a kind of open area near houses to facilitate planting of edible species. According to Sajogyo (1994), yard could play an important role as lumbung hidup (living barn) and warung hidup (living store). Suryanto et al. (2012) mentioned that yards as land used for cultivation and production, play an important role as the ecosystem warriors. Watson and Eyzaguire (2002) listed the following benefits from management of the yards: (i) source of family nutrition, (ii) saving of money, (iii) source of additional family income, and (iv) biodiversity conservation.

\section{ACKNOWLEDGMENTS}

Authors would like to thank the Head of Perkumpulan Badan Pendidikan Karya Bangsa Sintang and Head of STKIP Persada Khatulistiwa Sintang, Indonesia who provided financial assistance for this research.

\section{REFERENCES}

Adinugraha HA, Kartikawati NK, Setiadi D, Prastyono. 2014. Pengembangan Teknik Budidaya Sukun (Artocarpus altilis) untuk Ketahanan Pangan. IPB Press, Jakarta. [Indonesian]

Alexiades NM. 2003. Ethnobotany in the Third Millennium: expectations and unresolved issues. Delpinoa 45: 15-28.

Aryal PS. 2009. Ethnobotany of Tharu: Incorporation of Culture and Biodiversity Conservation (A case study of Jayanagar VDC of Kapilvastu District). [Thesis]. Central Department of Rural Development Faculty of Humanities and Social Sciences Tribhuvan University Kathmandu, Nepal.

Astawan M. 2009. Sehat dengan Hidangan Kacang dan Biji-bijian. Penebar Swadaya, Jakarta. [Indonesian]

Balick MJ, Cox PA. 1996. Plants, People and Culture: The Science of Ethnobotany. Scientific American Library, New York. 
Choudhary K, Singh M, Pillai U. 2008. Ethnobotanical Survey of Rajasthan-An Update. American-Eurasian Journal of Botany 1 (2) 38-45.

Cotton CM. 1996. Ethnobotany Principles and Applications. John Wiley and Sons Ltd, England.

Cunningham BA. 2001. Applied Ethnobotany People, Wild Plant Use and Conservation. Earthscan Publications Ltd, UK and USA.

Departemen Pertanian. 2003. Panduan Teknologi Pengolahan Sukun sebagai Bahan Pangan Alternatif. Direktorat Pengolahan dan Pemasaran Hasil Holtikultura, Jakarta. [Indonesian]

Desuciani A. 2012. Etnobotani pangan dan obat masyarakat sekitar Kawasan Taman Hutan Raya Wan Abdul Rachman: studi kasus pada Suku Lampung Pesisir. Institut Pertanian Bogor, Bogor. [Indonesian]

Diame ALG. 2010. Ethnobotany and Ecological Studies of Plants Used For Reproductive Health: A Case Study At Bia Biosphere Reserve In The Western Region Of Ghana. Final Report Submitted to The Division of Ecological Sciences UNESCO (MAB) Young Scientis Research Award Scheme Paris Cedex 15 France. UNESCO Accra Office, France.

Due R. 2013. Etnobotani Tumbuhan Obat Suku Dayak Pesaguan dan Implementasinya dalam Pembuatan Flash Card Biodiversitas. Universitas Tanjungpura, Pontianak. [Indonesian]

Farneubun TM. 2014. Etnobotani pangan dan obat masyarakat Suku Ke Kampung Adat Waur Kei Besar Maluku Tenggara. Institut Pertanian Bogor, Bogor. [Indonesian]

Fitrianti L. 2012. Hutan Adat: Milik Pemerintah atau Milik Masyarakat http: //Jurnalhijau.wordpress.com/2012/07/04/hutan-adat-milikpemerintah-atau-milik-masyarakat. [Indonesian]

Gunawan H. 2014. Dampak Rencana Pembangunan Jalan Melintasi Kawasan Lindung Terhadap Keseimbangan Ekosistem Dan Habitat. Makalah disampaikan pada National Inception Workshop dengan tema "Membangun Ketahanan Hutan Hujan Tropis Sumatera untuk Mitigasi Perubahan Iklim dan Keanekaragaman Hayati”. Santika Dyandra, Medan, 23-24 September 2014. [Indonesian]

Hakim L. 2014. Etnobotani dan Manajemen Kebun-Pekarangan Rumah: Ketahanan Pangan, kesehatan dan agrowisata. Selaras, Malang. [Indonesian]

Hulyati R, Syamsuardi, Arbain A. 2014. Studi Etnobotani pada Tradisi Balimau di Kota Pariaman, Sumatera Barat (Ethnobotany Studies of Balimau Tradition in Pariaman, West Sumatera). Jurnal Biologi Universitas Andalas (J. Bio. UA) 3 (1): 14-19. [Indonesian]

Junaidah, Suryanto P, Budiadi. 2015. Komposisi Jenis dan Fungsi Pekarangan (Studi kasus desa Giripurwo, Kecamatan Girimulyo, DI Yogyakarta), The Species Composition and Function Of Home Garden (The Case Study at Giripurwo Village, Girimulyo Subdistrict, Yogyakarta). Jurnal Hutan Tropis 4 (1): 77-84. [Indonesian]

Keraf SA. 2002. Etika Lingkungan, Pn. Buku Kompas, Jakarta. KMNLH. 2007. Status Lingkungan Hidup Indonesia, Jakarta. [Indonesian]

Lempang M dan Suhartati. 2013. Potensi Pengembangan Cempedak (Artocarpus integer Merr.) pada Hutan Tanaman Rakyat Ditinjau Dari Sifat Kayu dan Kegunaannya. Info Teknis EBONI 10 (2): 6983. [Indonesian]

Lushaini S, Wibowo MA, Ardiningsih P. 2015. Kandungan Total Fenol, Aktivitas Antioksidan dan Sitotoksik Daun Kedadai (Ficus variegate Blume). JKK 4 (2): 1-5. [Indonesian]

Martin GJ. 1995. Ethnobotany: A Methods Manual. Chapman and Hall, London.

Mesfin K, Tekle G, Tesfay T. 2013. Ethnobotanical Study of Traditional Medicinal Plants Used by Indigenous People of Gemad District, Northern Ethiopia. Journal of Medicinal Plants Studies 1 (4): 32-37.
Munawaroh. 2000. Peran Etnobotani dalam Menunjang Konservasi ExSitu Kebun Raya. Balai Pengembangan Kebun Raya - LIPI, Bogor. [Indonesian]

Nopandry B. 2007. Hutan untuk masyarakat pemanfaatan lestari hutan konservasi. Buletin Konservasi Alam 7 (1): 4-8. [Indonesian]

Nugraha A, Murtijo. 2005. Antropologi Kehutanan. Wana Aksara, Tangerang. [Indonesian]

Pie S, Xiu J. 2002. Applied Ethnobotany: Participatory Approach forCommunity Development and Conservation. Chinese Journal of Ecology 21 (6): 40-46.

Pieroni A, Anely N, Avni H, Mustafa B, Bruno S, Kevin C, Cassandra LQ. 2014. Local knowledge on plant and domestic remedies in the mountain village of Peshkopia (Eastern Albania). J Mt Sci 11 (1): 180-194.

Pitojo S. 2005. Benih Tomat. Kanisius, Yogyakarta. [Indonesian]

Puspitojati T, Mile MY, Fauziah E, Darusman D. 2014. Hutan Rakyat Sumbangsih Masyarakat Pedesaan untuk Hutan Tanaman. Kanisius, Yogyakarta. [Indonesian]

Reta H. 2010. An Ethnobotanical Study Of Useful Plants Of The Farming Site In Gozamen Mereda, East Gojjam Zone Of Amhara Region, Ethiopia. Addis Ababa University School of Graduate Studies, Ethiopia.

Sajogyo. 1994. Munuju Gizi Baik yang Merata di Pedesaan dan di Kota. Gajah Mada Press, Yogyakarta. [Indonesian]

Supiandi MI, Mahanal S, Zubaidah S, Julung H, Ege B. 2019. Ethnobotany of traditional medicinal plants used by Dayak Desa Community in Sintang, West Kalimantan, Indonesia. Biodiversitas 20 (5): 1264-1270.

Suryanto P, Widyastuti SM, Sartohadi J, Awang SA, Budi. 2012. Traditional Knowledge of Homegarden-Dry Field Agroforestry as a Tool for Revitalization Management of Smallholder Land Use in Kulon Progo Java, Indonesia. International Journal of Biology 4 (2).

Sutedjo U. 2004. Pengembangan Kultur Tumbuhan Berkhasiat Obat. Rineka Citra, Jakarta. [Indonesian]

Tamalene MN. 2016. Perspektif Konservasi Berbasis Kearifan Lokal dan Etnobiologi Keanekaragaman Hayati Suku Togutil di Pulau Halmahera sebagai Bahan Pengembangan Buku Referensi Etnokonservasi. [Disertation]. State University of Malang, Malang. [Indonesian]

Tamin R, Arbain D. 1995. Biodiversity dan Survey Etnobotani. Makalah Loka Karya Isolasi Senyawa Berkhasiat. Universitas Andalas, Padang. [Indonesian]

Tesfaye H, Sebsibe D, Zemede. 2009. An Ethnobotanical Study of medicinal plants used by local people in the lowlands of Konta Special Wereda, Sothern Nations, Nationalities and People Regional State, Ethiopia. Journal of Ethnobiology and Ethnomedicine 6 (25).

Tjitrosoepomo G. 2005. Taksonomi Umum Dasar-dasar Taksonomi Tumbuhan. Gadjah Mada University Press, Yogyakarta. [Indonesian]

Watson JW, Eyzaguire PB (eds). 2002. Home gardens and in situ conservation of plant genetic resources in farming system. Proceedings of the Second International Home gardens Workshop, Witzenhausen, Federal Republic of Germany, 17-19 July 2001.

Whitten T, Soeriaatmadja RE, Afiff SA. 1996. The ecology of Indonesia series volume II: The ecology of Java and Bali. Periplus, Hongkong.

Widowati S. 2003. Prospek Tepung Sukun untuk Berbagai Produk Makanan Olahan dalam Upaya Menunjang Diversifikasi Pangan. http: //tumotou.net/70207134/sri_widowati.html. [Indonesian]

Zheng H, Wu Y, Ding J, Binion D, Fu W, Reardon R. 2006. Invasive Plant of Asian Origin Established in The United State and Their Natural Enemies. Forest Health Technology Enterprise Team, Morgantown, WV, USA. 